\title{
An assessment of technical and economic feasibility to install geothermal well systems across Ukraine
}

\author{
Dmytro Rudakov* (1) and Oleksandr Inkin
}

\author{
*Correspondence: \\ rudakov.d.v@nmu.one \\ Department \\ of Hydrogeology \\ and Engineering Geology, \\ National Mining University, \\ D. Yavornytskyi Avenue, 19 \\ Dnipro 49005, Ukraine
}

\begin{abstract}
Although the resources of geothermal energy in Ukraine greatly exceed domestic conventional energy sources, using geothermal heat in the country is still far behind the existing opportunities. Addressing this gap requires a large-scale pre-feasibility assessment with proper account for hydrogeological and economic factors to facilitate identifying the most promising areas of the country for efficient use of geothermal energy. One of the well-known technologies in this field is a geothermal well system (GWS) that combines pumping out thermal waters, extracting heat on the ground, and reinjecting cooled water back to the aquifer. In this study, we created the maps of expected thermal output and profitability of the doublet GWS across Ukraine for minimum and maximum values of depth and flow rate of thermal waters applying analytical methods of heat transfer in saturated rocks in combination with the net present value (NPV) as a generally accepted economic criterion. Map analysis showed that the GWS maximum expected thermal output might reach 5-9 MW in the Black Sea coastal area and steppe Crimea at the flow rate exceeding $1500 \mathrm{~m}^{3} /$ day and aquifer depth of $2 \mathrm{~km}$ and more. The NPV index is positive for the most part of Ukraine and increases up to 7-17 million $€$ in southern regions of the country. Calculating performance parameters for two potential GWS sites showed a higher thermal output for a GWS in the Black Sea coastal area compared to the site in Transcarpathia but comparable NPV for both sites due to lower installation costs in the western part of the country.
\end{abstract}

Keywords: Thermal waters, Geothermal well system, Thermal output, Net present value, Mapping

\section{Introduction}

In 2004, the total installed capacity of geothermal plants located in 24 countries of the world still amounted to $8.91 \mathrm{GW}$ with an annual power generation of $56.8 \mathrm{TWh}$; in 2009, these indices grew up to $10.71 \mathrm{GW}$ and $67.2 \mathrm{TWh}$, respectively; in 2014 these indices reached 12.64 GW and 73.55 TWh (Erdlac et al. 2006; Bertani 2015; Shulyupin and Chernev 2015). Details of installed capacity distribution over the world and development trends were reported by Gehringer and Loksha (2012). In the same period, the annual electricity generation based on geothermal energy increased from 56.8 to $73.55 \mathrm{TWh}$. In recent years, geothermal energy use was growing most rapidly in Kenya (+392 MW), USA (+352 MW), Turkey (+306 MW), New Zealand (+243 MW), 
Indonesia (+143 MW), Iceland (+90 MW) and Italy (+73 MW) (Busby and Terrington 2017; Cabrera et al. 2017). Currently, geothermal reservoirs are exploited in more than 70 countries. Industrial thermal power plants in 58 countries operate with a total installed capacity of $16.4 \mathrm{GW}$ and an annual thermal output of 191,500 TJ, saving 8.2 million tons of fossil fuels. By 2020 the total installed capacity of geothermal power in the world is expected to increase to 21.4 GW (Tester et al. 2006; Mahler and Magtengaard 2010; Shnell et al. 2015).

The application of geothermal heat supply systems is not only saving fossil fuels but also contributing to the solution of numerous environmental problems, especially reducing greenhouse gas emissions in industrial megacities (Hashida et al. 2000; Mhitaryan and Machulin 2006; Dolinskyi and Obodovych 2016; Bayer et al. 2016). Owing to renewability, the use of geothermal plants facilitates keeping the overall energy balance of the country (Kong et al. 2014; Reinsch et al. 2016). Geothermal well systems (GWS) are of wide and growing use in the USA, Switzerland, Germany, Denmark, Poland, and Russia (Kepinska 2010); such systems installed in reservoirs at depth of 1.5-3 km have the thermal output of 1-10 MW. In 2001 GWSs provided 45,000 dwelling equivalents in France with heat and electricity (Arens 2001); by 2013 this amount grew to 200,000 mostly in metropolitan Paris according to ADEME (2013).

Limited reserves of oil and natural gas in Ukraine raised the significance of searching for alternative sources to provide heat supply systems in municipal and industrial facilities of the country with thermal energy. The total resources of geothermal energy in Ukraine to a depth of $10 \mathrm{~km}$-which can be interpreted as the country's theoretical potential based on definitions of Rybach (2010) - are estimated at $10^{22} \mathrm{~J}$, which is equivalent to $3.4 \times 10^{11}$ tonnes of fuel and significantly exceeds the reserves of conventional sources estimated at $10^{12} \mathrm{~m}^{3}$ of natural gas, $5.36 \times 10^{10}$ tonnes of coal, and $4 \times 10^{8}$ tonnes of oil; according to Limarenko (2012), the economically viable energy resource of thermal waters in Ukraine is estimated at 8.4 million tonne of oil equivalent per year (IRENA 2015). Comparing the existing resources of geothermal energy with the state of the art of this industry in the country clearly indicates its use insufficiency.

The total thermal output of geothermal plants in Ukraine of $11 \mathrm{MW}$ according to Maliarenko et al. (2012) is much less than that in many other countries with comparable geological conditions. The operating plants cover mostly local heat and electricity needs of such individual objects as sanatoriums and sports facilities in small settlements. Nine geothermal plants of total heat capacity $10.8 \mathrm{MW}$ and electric capacity $0.2 \mathrm{MW}$ currently being under operation in the country are unevenly distributed throughout its territory as follows: three plants are in the Transcarpathian region, one is in Kherson, and five are in the Crimea according to Dolinskyi and Rezakova (2017).

The recent studies (Dolinskyi and Obodovych 2016; Moya et al. 2018) made quite general estimations for wide intervals of depth without paying due attention to hydrogeological conditions, water cooling during operation; these studies did not use modern economic criteria. At the same time, nowadays GWS installation for long-term operation requires significant capital investments usually covered by different sources and credits; thus, the investment return for potential geothermal sites should be properly justified right at the design stage by modern economic indicators like the net present value (NPV). Therefore, there is a growing need for a detailed large-scale pre-feasibility 
assessment to identify the most promising regions of the country in terms of technical and economic feasibility of geothermal well systems taking into account hydrogeological conditions and technical specifics like those presented in Busby and Terrington (2017). In general, various designs for geothermal energy installations are used in the world, including fountains, parallel heating and hot water supplies, peak water heating, heat pumps; however, due to their diversity, this paper focuses on a doublet design comprising one production and one abstraction well.

On the whole, this study aims at regional-scale zoning and nationwide mapping the potential efficiency of doublet geothermal heat supply systems for buildings and the profitability of their operation based on common investment criteria. The first step should be identifying zones with hydrogeological parameters to be used for mapping. The second one involves justifying the suitable geotechnological design of a geothermal unit regarding to hydrogeological parameters, technical and economic limitations. And finally, the thermal output and profitability evaluated for a selected design should be mapped for the country.

\section{Geothermal and hydrogeological conditions}

The geothermal conditions of Ukraine (Fig. 1) studied by Gordienko et al. (2002) and Lukinov et al. (2018) vary across the regions of the country (Table 1). In the west, within the fold province of the Carpathians, an average heat flux of $100 \mathrm{~mW} /$ $\mathrm{m}^{2}$ causes relatively high groundwater temperature that reaches $65-70{ }^{\circ} \mathrm{C}$ at a depth of $1 \mathrm{~km}$ and $100-110{ }^{\circ} \mathrm{C}$ at the depth of $2 \mathrm{~km}$. Further to the east in Volyn-Podilsky plate, the heat flux gradually decreases to $50-70 \mathrm{~mW} / \mathrm{m}^{2}$ that causes decreasing

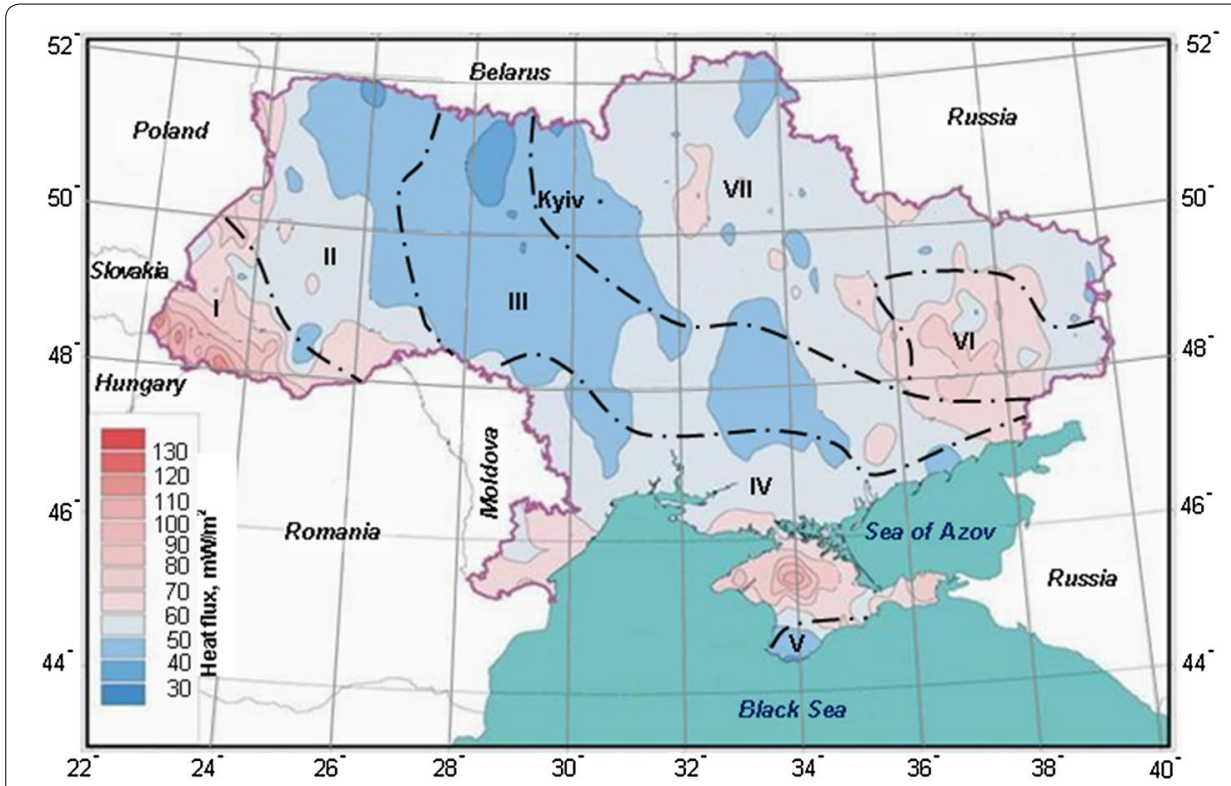

Fig. 1 The map of heat flux distribution and hydrogeological provinces across Ukraine (National Atlas of Ukraine 2007; Shestopalov et al. 1988). I refers to Fold province of the Carpathians (west); II Volyn-Podilsky artesian basin (northwest); III Fold province of Ukrainian crystalline shield (central part); IV the Black Sea artesian basin (south); V Fold province of the Mountainous Crimea (Crimean Peninsula); VI Fold province of the Donets basin (east); VII the Dnipro-Donets artesian basin (north-east) 
Table 1 Temperature and flow rates of thermal waters in the hydrogeological provinces across Ukraine (province boundaries can be seen on Fig. 1)

\begin{tabular}{|c|c|c|c|c|}
\hline Hydrogeological area & Depth, km & Aquifers, age & $\begin{array}{l}\text { Groundwater } \\
\text { temperature, }{ }^{\circ} \mathrm{C}\end{array}$ & Flow rate, $\mathrm{m}^{3} /$ day \\
\hline \multirow[t]{2}{*}{$\begin{array}{l}\text { I. Fold province of the } \\
\text { Carpathians (west) }\end{array}$} & $0.6-0.9$ & $\begin{array}{l}\text { Sandstones and limestones, } \\
\mathrm{N}_{1}^{3}\end{array}$ & $50-75$ & $430-1200$ \\
\hline & $1.9-2.3$ & Sands, $N_{1}^{2}$ & $120-130$ & $5-10$ \\
\hline \multirow[t]{2}{*}{$\begin{array}{l}\text { II. Volyn-Podilsky artesian } \\
\text { basin (northwest) }\end{array}$} & $0.9-1.1$ & $\begin{array}{l}\text { Fractured sandstones and } \\
\text { limestones, D }\end{array}$ & $35-45$ & $20-40$ \\
\hline & $1.8-2.0$ & $\begin{array}{l}\text { Fractured sandstones and } \\
\text { limestones, D }\end{array}$ & $60-70$ & $20-40$ \\
\hline \multirow{2}{*}{$\begin{array}{l}\text { III. Fold province of Ukrain- } \\
\text { ian crystalline shield } \\
\text { (central part) }\end{array}$} & $0.8-1.0$ & $\begin{array}{l}\text { Karstified Dolomite Marbles, } \\
\text { PR }\end{array}$ & $30-35$ & $300-400$ \\
\hline & $1.9-2.4$ & Granites, PR & $50-55$ & $50-100$ \\
\hline \multirow[t]{2}{*}{$\begin{array}{l}\text { IV. The Black Sea artesian } \\
\text { basin (south) }\end{array}$} & 1.5 & $\begin{array}{l}\text { Chalky clay and sandstones, } \\
\text { K }\end{array}$ & 50 & $500-1500$ \\
\hline & 3.0 & $\begin{array}{l}\text { Chalky clay and sandstones, } \\
\text { K }\end{array}$ & 90 & $500-1500$ \\
\hline \multirow[t]{2}{*}{$\begin{array}{l}\text { V. Fold province of the } \\
\text { Mountainous Crimea } \\
\text { (Crimean Peninsula) }\end{array}$} & 1.1 & $\begin{array}{l}\text { Karstified limestone and } \\
\text { sandy-argillaceous rocks, } \\
\mathrm{T}_{3}-J_{2}\end{array}$ & $30-35$ & $10-20$ \\
\hline & 1.9 & $\begin{array}{l}\text { Karstified limestone and } \\
\text { sandy-argillaceous rocks, } \\
\mathrm{T}_{3}-J_{2}\end{array}$ & $65-70$ & $10-20$ \\
\hline \multirow[t]{2}{*}{$\begin{array}{l}\text { VI. Fold province of the } \\
\text { Donets basin (east) }\end{array}$} & $0.9-1.2$ & $\begin{array}{l}\text { Fractured and fractured- } \\
\text { karstified limestones, } D_{2}\end{array}$ & $27-40$ & $200-400$ \\
\hline & $1.8-2.0$ & $\begin{array}{l}\text { Sandstones and conglom- } \\
\text { erates, } D_{2}\end{array}$ & $70-75$ & $75-150$ \\
\hline \multirow{2}{*}{$\begin{array}{l}\text { VII. The Dnipro-Donets arte- } \\
\text { sian basin (north-east) }\end{array}$} & $1-1.2$ & Sands and sandstones, $\mathrm{P}$ & $35-60$ & $10-250$ \\
\hline & $1.9-2.3$ & $\begin{array}{l}\text { Fractured sandstones and } \\
\text { limestones, D }\end{array}$ & $50-90$ & $80-500$ \\
\hline
\end{tabular}

Data are given according to Gordienko et al. (2002), Maliarenko et al. (2002), Mhitaryan and Machulin (2006)

temperature of groundwater to $35-40{ }^{\circ} \mathrm{C}$ and $60-70{ }^{\circ} \mathrm{C}$ at the depths of $1 \mathrm{~km}$ and $2 \mathrm{~km}$, respectively. In the central part of the country covered by Ukrainian Crystalline Shield, the geothermal flux does not exceed $40 \mathrm{~mW} / \mathrm{m}^{2}$, which results in low water temperatures below $35{ }^{\circ} \mathrm{C}$ at a depth of $1 \mathrm{~km}$ and only $55{ }^{\circ} \mathrm{C}$ at a depth of $2 \mathrm{~km}$. The higher values of the geothermal flux are evaluated in the southern and north-eastern regions of the country (the Black Sea coast and the Dnipro-Donets artesian basin) where its value reaches $50-60 \mathrm{~mW} / \mathrm{m}^{2}$ and groundwater temperature ranges from 45 to $65^{\circ} \mathrm{C}$ within the depth interval of $1-2 \mathrm{~km}$.

A specific case of geothermal resources is man-made thermal waters that were the focus of some recent studies related to flooded coal mines, particularly, to the feasibility of creating man-made geothermal reservoirs on the base of the significant reserves of low-grade coal in closed Ukrainian mines estimated at 30 billion tons (Timoshuk et al. 2012; Rudakov et al. 2012). This process is based on aquifer heating by burning the underlying coal seams of low thickness (Dychkovskyi 2015; Pivnyak et al. 2018). The largest industrial experiment in underground coal gasification conducted in the USA at the Rocky Mountains site in 1987-1988 reported by Camp and White (2015) and Berdan (1986) demonstrated the significant potential of a creating a thermal source with the temperature exceeding $100{ }^{\circ} \mathrm{C}$ in the early stages of coal combustion. 
At the same time, the operation of such a thermal source is highly dependent on local geological setting, time, and is often restricted by environmental regulations.

For this reason, in the following study we consider the well-known design of water circulation in a doublet of wells that implies extracting heat on the ground and reinjecting cooled water back to the aquifer.

\section{Technology design}

Most thermal waters in Ukraine are highly mineralized, and their discharge to surface water bodies after cooling is unacceptable due to environmental restrictions. As an alternative to discharge, open geothermal well systems (GWSs) (Fig. 2) are getting wider use that include (1) pumping of thermal waters to the ground surface, (2) on-ground heat recovery, and (3) deep reinjection of cooled water into the subsurface (Alsakhov 2012; Zeng et al. 2017). Such a system significantly enhances the efficiency of geothermal heat recovery since it uses both groundwater heat and rock heat.

To avoid corrosion and scaling, heat is extracted by using intermediate heat exchangers. Water pumped by the production well is accumulated in the storage tank and then is delivered to the heat exchanger. Heated water is delivered to consumers whilst cooled groundwater is pumped back into the reservoir through the injection well. The system often consists of one production well and one reinjection well (a doublet); however, more complicated designs do exist.

The GWS performance efficiency depends on combination of hydrogeological, technical, and economic indicators including groundwater temperature and chemical content, water

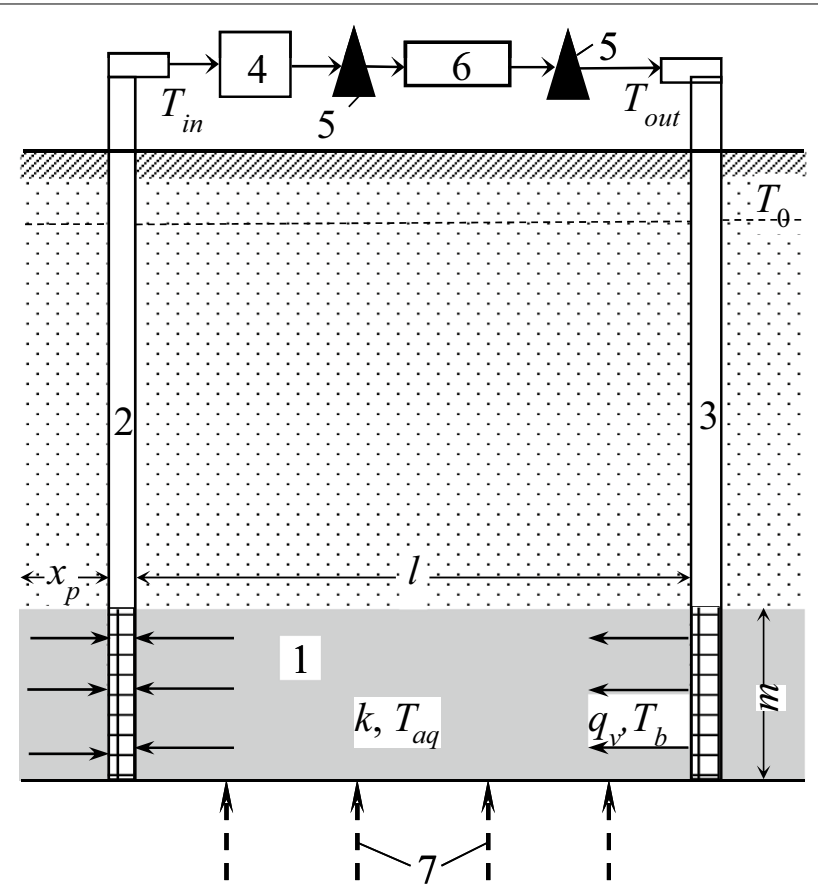

Fig. 2 Principal sketch to evaluate GWS thermal output. 1-reservoir; 2, 3-production and injection wells, respectively; 4-accumulator; 5-pumps; 6- heat exchanger; 7-geothermal flux; the other notations can be seen in the text 
intake parameters, installation costs (drilling), the cost of electricity for pumping groundwater, etc. (Red'ko and Bugai 2010). Permanent circulation of water resulting in gradual aquifer cooling should be also taken into account. Therefore, the GWS thermal output and efficiency have to be evaluated by coupling appropriate hydrogeological and heat transfer models with economic criteria taking into account local consumers' demands and development trends.

\section{Methods}

Since the cost of GWS installation and operation depends on many factors and may greatly vary for each site, we will focus on the large-scale assessment taking into consideration such main common input items as (1) well drilling, (2) industrial equipment, and (3) electricity for pumping, which can give preliminary cost estimation for a GWS.

The drilling cost of deep wells in Ukraine regarding to the complexity of geological settings can be estimated within the range $200-300 €$ per running metre (Filatov and Zaharchenko 2012), which is less than in the international practice (Bai and Patil 2014) due to lower local prices. The cost of required industrial equipment (pumps, pipes, and storage tanks) can be estimated at $20-25 \%$ of drilling cost (Red'ko and Bugai 2010). The power consumed by centrifugal pumps for abstraction and reinjection of groundwater can be calculated by the formula (Ishlinskyi 1989; Bugai 2014)

$$
N_{\text {abst }}=k_{\mathrm{z}} \frac{Q H \rho_{\text {inj }} g}{\eta_{\mathrm{p}} \eta_{\mathrm{tr}}}, \quad N_{\text {inj }}=k_{\mathrm{z}} \frac{Q P_{\text {inj }}}{\eta_{\mathrm{p}} \eta_{\mathrm{tr}}},
$$

where $N_{\text {abst }}$ is the pump rate for water abstraction, $N_{\text {inj }}$ the pump rate for water injection, $k_{\mathrm{z}}$ the safety factor for a pump that depends on its motor type; $g$ the gravitational acceleration; $Q$ the well flow rate; $H$ the reservoir depth; $\rho_{\text {inj }}$ and $P_{\text {inj }}$ the density and pressure of injected water; and $\eta_{\mathrm{p}}$ and $\eta_{\mathrm{tr}}$ the efficiency of the pump and mechanical transmission of rotational motion from the engine to the pump, respectively.

Electric centrifugal pumps are recommended to apply in GWS due to their trouble-free operation in corrosive liquids containing dissolved salts, gases, and mechanical impurities. The pumps of this type use simple equipment on the ground, have a long lifespan of $2-3$ years and can be used for wells of up to $4 \mathrm{~km}$ depth providing a significant flow rate up to $5000 \mathrm{~m}^{3} /$ day.

The GWS installation cost $C$ can be calculated by the following formula taking into account the recommendations of Filatov and Zaharchenko (2012)

$$
C=L_{\mathrm{w}} s_{\mathrm{w}}\left(1+p_{\mathrm{w}} / 100\right),
$$

where $L_{\mathrm{w}}$ is the length of the well, $s_{\mathrm{W}}$ is the drilling cost per a running metre of the well, $p_{\mathrm{w}}$ the per cent share of the equipment costs with respect to the total drilling costs.

Taking the weighted average drilling cost for one linear metre of a well at $235 €$ plus $20 \%$ for the equipment cost, we can evaluate the initial cost for GWS installation at 564,000 $€$ per $1 \mathrm{~km}$ of the depth.

The power consumption $W$ and its cost $S_{\mathrm{p}}$ are calculated by the formulae

$$
W=\left(N_{\mathrm{abst}}+N_{\mathrm{inj}}\right) t_{\mathrm{op}}, \quad S_{\mathrm{p}}=W s_{\mathrm{el}}
$$


where $t_{\mathrm{op}}$ is the operation time and $s_{\mathrm{el}}$ the electricity tariff for consumers in industries. The last parameter $s_{\mathrm{el}}$ varied during last years in Ukraine and now can be evaluated as the equivalent to $5.8 €$ for $100 \mathrm{kWh}$ for industries at the average exchange rate.

Calculation results for the well depth $H$, flow rate $Q$ and other parameters $\left(k_{\mathrm{z}}=1.2\right.$, $P_{\text {inj }}=1.5 P_{\text {aq }}, P_{\text {aq }}=\rho_{\text {inj }} g H, \eta_{\mathrm{n}}=0.6, \eta_{p}=0.9$, where $P_{\text {aq }}$ is the water pressure in the aquifer) are given in Table 2 .

The profit Pr gained from the GWS operation can be evaluated as the difference between the cost of generated heat $S_{\mathrm{h}}$ and the cost of power consumed by the pumps $S_{\mathrm{p}}$

$$
\operatorname{Pr}=S_{\mathrm{h}}-S_{\mathrm{p}}, \quad S_{\mathrm{h}}=U s_{\mathrm{th}} t_{\mathrm{op}}
$$

where $U$ is the GWS thermal output calculated by the formula

$$
U=Q C_{\mathrm{v}}\left(T_{\text {in }}-T_{\text {out }}\right),
$$

where $C_{\mathrm{v}}, T_{\mathrm{in}}, T_{\text {out }}$ are the volumetric heat capacity of water, its average temperature before and after use, respectively. In Eq. $4 s_{\text {th }}$ is the average tariff for thermal energy; it varied across the country and now can be evaluated at $47.2 €$ for $1 \mathrm{GCal}(4.18 \mathrm{GJ})$.

Calculations to be performed by Eq. 5 are associated with the uncertainty in evaluating output temperature $T_{\text {out }}$ that has to be found as the solution to an optimization problem. On the one hand, decreasing temperature of circulating water on the surface results in increasing water density and pressure in the injection well, thus causing pumping costs to grow. On the other hand, injected water temperature should not significantly change the thermodynamic conditions near the well bottom and thereby affect the GWS thermal output.

As a preliminary approximation, the following system of equations can be used to evaluate $T_{\text {out }}$ (Alsakhov 2012)

$$
\begin{aligned}
& \Delta T_{\mathrm{b}}=\Delta T_{\mathrm{out}} e^{-H \beta}+\mathrm{GH}-\frac{G}{\beta}\left(1-e^{-H \beta}\right), \\
& \Delta T_{\mathrm{out}}=T_{\text {out }}-T_{0}, \quad T_{\mathrm{in}}=T_{\mathrm{b}}+\left(T_{\mathrm{aq}}-T_{\mathrm{b}}\right) e^{-Q t / V_{p}}, \quad \Delta T_{\mathrm{b}}=T_{\mathrm{b}}-T_{0}, \\
& \beta=\frac{\pi K}{Q C_{\mathrm{v}}}, \quad G=\frac{q}{\lambda}, \quad K=2 /\left(\frac{1}{\lambda} \ln \frac{r_{\mathrm{t}}}{r_{\mathrm{w}}}\right), r_{t}=2 \sqrt{a t}, \quad T_{\mathrm{aq}}=T_{0}+G\left(H-H_{0}\right),
\end{aligned}
$$

where $T_{\mathrm{b}}, T_{0}$ are water temperatures at the injection well bottom and the rocks at a depth of the neutral layer with unchanged temperature, respectively; $T_{\mathrm{aq}}$ the water temperature in the aquifer; $T_{\text {in }}$ the temperature of thermal water before its use; $G$ the

\begin{tabular}{|c|c|c|c|c|c|c|}
\hline$H, \mathrm{~m}$ & 1000 & & & 2000 & & \\
\hline Q, m³/day & 100 & 500 & 1000 & 100 & 500 & 1000 \\
\hline$W, \mathrm{~kW}$ & 54.17 & 275 & 545.83 & 108.83 & 545.83 & 1091.67 \\
\hline$S_{p}, € /$ day & 75 & 360 & 760 & 150 & 760 & 1520 \\
\hline
\end{tabular}
geothermal gradient; $q$ the geothermal heat flux; $H$ the depth of the well bottom; $H_{0}$ the depth of the neutral layer; $t$ time; $V_{\mathrm{p}}$ the volume of rocks through which water circulates; $r_{\mathrm{t}}$ the radius of well thermal influence; $r_{\mathrm{W}}$ the well radius; $\lambda$ and $a$ the thermal

Table 2 Consumption and the cost of power to maintain water circulation in the GWS 
conductivity and thermal diffusivity of rocks (see Fig. 2). We assume the temperature of injected water $T_{\text {inj }}$ to be equal to the temperature of cooled backwater $T_{\text {out }}$.

The volume of rocks $V_{\mathrm{p}}$ in Eq. 7 can be estimated as the size of the well capture zone area that encloses the water volume completely pumped out by the well during its operation. Regarding the long-term water injection and seepage over the entire reservoir thickness, this area can have the form of an elliptical cylinder elongated along the groundwater flow with its height $h$ being equal to the aquifer thickness, the major axis $l$ being the distance between the injection and production wells, and minor axis $d$ being calculated as proposed by Oradovskaya and Lapshin (1987).

For complicated designs including three or more wells, more sophisticated calculation methods should be applied including numerical models of flow and heat transport in saturated rocks.

A comprehensive assessment of GWS profitability under various conditions can be performed using the NPV as the criterion accepted in international practice of investment analysis. This indicator is defined as the amount of expected net profit to be received by the investor as a result of GWS installation and operation. The NPV can be calculated following Michaelides (2012)

$$
\mathrm{NPV}=-C+\sum_{i=1}^{25} \frac{\operatorname{Pr}_{i}}{(1+R)^{i}}
$$

where $C$ is GWS installation cost; $\operatorname{Pr}_{i}$ is the annual profit from the GWS operation during $i$-th year of operation calculated at the appropriate temperature difference (see also Eq. 5); $R$ is the discount rate; and 25 years are taken as the expected period of operation for such kind of industrial facilities in the country. Besides, $\operatorname{Pr}_{i}$ should include the other relevant costs including those for personnel. Thus, Eq. 8 provides the preliminary feasibility criterion (NPV $>0$ ) to invest to a GWS project that has to be refined in more detailed feasibility studies.

\section{Results and discussion}

We evaluated the GWS thermal output and profitability taking into account local geological settings (Table 1) and assuming mean values of thermodynamic and some hydrogeological parameters listed in Table 3.

Following the variability of geological conditions across Ukraine and technical limitations, we varied geothermal flux $q$ from 60 to $100 \mathrm{~mW} / \mathrm{m}^{2}$ and flow rate $Q$ from 100 to $1500 \mathrm{~m}^{3} /$ day. The GWS performance is predicted for a period of 25 years as the expected operation time. The results of calculations are depicted in Figs. 3 and 4.

The initial temperature of injected water $T_{\text {out }} 15^{\circ} \mathrm{C}$ at the flow rate of $500 \mathrm{~m}^{3} /$ day may rise by almost $12{ }^{\circ} \mathrm{C}$ when reaching the bottom of the extraction well at the depth of $3 \mathrm{~km}$ and only by $1.5{ }^{\circ} \mathrm{C}$ when reaching smaller depth of $1 \mathrm{~km}$. By the end of the operation period of 25 years, the difference in temperature of abstracted water and reinjected water may decrease by $17-26 \%$ within the evaluated ranges of depth and flow rate, which reduces the GWS thermal output and its economic efficiency accordingly.

The decreasing temperature of water pumped out in the operation period allows evaluating the rate of aquifer cooling due to water circulation (Fig. 3). Triplicating the 
Table 3 Parameters used for calculations

\begin{tabular}{llll}
\hline Designation & Parameter & Value & Unit \\
\hline$a$ & Thermal diffusivity of rocks & 0.086 & $\mathrm{~m}^{2} /$ day \\
$C_{v}$ & Volumetric heat capacity of water & 4.2 & $\mathrm{MJ} /\left(\mathrm{m}^{3}{ }^{\circ} \mathrm{C}\right)$ \\
$H_{0}$ & The depth of the neutral layer & 10 & $\mathrm{~m}$ \\
$I_{0}$ & Groundwater head pressure gradient & 0003 & - \\
$k$ & Rock conductivity & 2 & $\mathrm{~m} / \mathrm{day}$ \\
$I$ & Distance between injection and pumping wells & 800 & $\mathrm{~m}$ \\
$m$ & Aquifer thickness & 20 & $\mathrm{~m}$ \\
$n$ & Active porosity & 0.2 & - \\
$r_{w}$ & Well radius & 0.1 & $\mathrm{~m}$ \\
$T_{0}$ & Water temperatures in rocks at a depth of the neutral layer & 10 & ${ }^{\circ} \mathrm{C}$ \\
$T_{\text {out }}$ & Cooled water temperature & $5-15$ & ${ }^{\circ} \mathrm{C}$ \\
$\lambda$ & Thermal conductivity of rocks & 1.8 & $\mathrm{~W} /\left(\mathrm{m}^{\circ} \mathrm{C}\right)$ \\
inj & Density of injected water & $1016-1056$ & $\mathrm{~kg} / \mathrm{m}^{3}$ \\
\hline- denotes dimensionless parameters
\end{tabular}
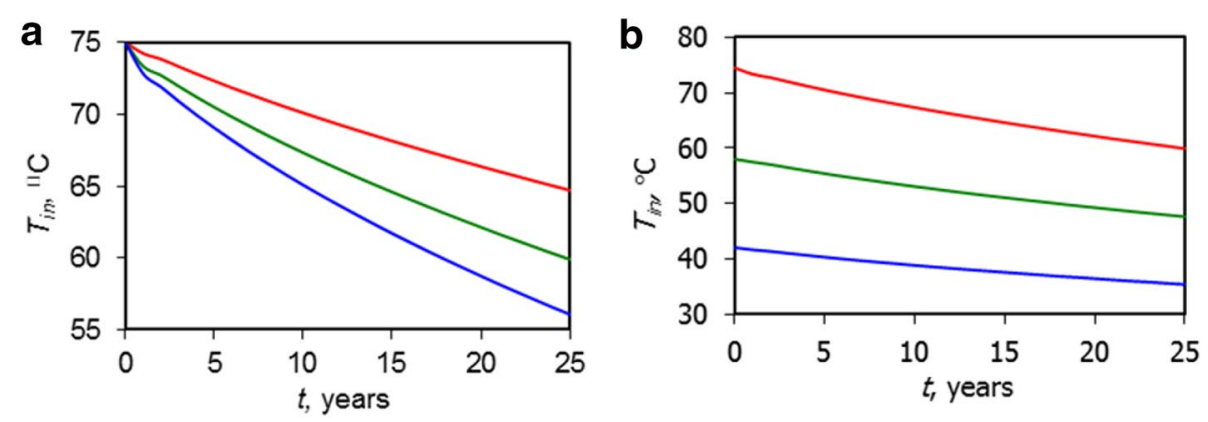

Fig. 3 Pumped water temperature versus time: a for $H=2 \mathrm{~km}$ and flow rates $Q=500 \mathrm{~m}^{3} /$ day (red), $Q=1000 \mathrm{~m}^{3} /$ day (green), $Q=1500 \mathrm{~m}^{3} /$ day (blue); $\mathbf{b}$ for $Q=1000 \mathrm{~m}^{3} /$ day and depths $H=2 \mathrm{~km}$ (red), $H=1.5 \mathrm{~km}$ (green), $H=1 \mathrm{~km}$ (blue). The other parameters are $q=60 \mathrm{~mW} / \mathrm{m}^{2}, T_{\text {out }}=15^{\circ} \mathrm{C}$
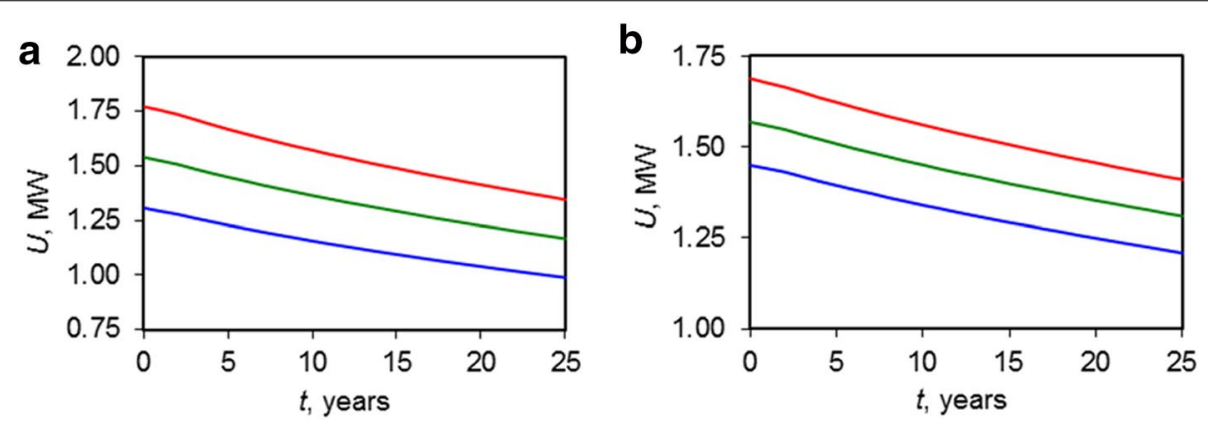

Fig. 4 GCS heat output versus time: a $H=1 \mathrm{~km}, \mathrm{Q}=1000 \mathrm{~m}^{3} /$ day; $\mathbf{b} H=2 \mathrm{~km}, \mathrm{Q}=500 \mathrm{~m}^{3} /$ day; $q=60 \mathrm{~mW}$ / $\mathrm{m}^{2} ; T_{\text {out }}=5^{\circ} \mathrm{C}$ (red), $10^{\circ} \mathrm{C}$ (green) and $15^{\circ} \mathrm{C}$ (blue)

flow rate results in faster cooling of the aquifer; by the end of the operation period, the temperature difference is expected to reduce by $17.6 \%$ at $Q=500 \mathrm{~m}^{3} /$ day and by $32.4 \%$ at $Q=1000 \mathrm{~m}^{3} /$ day (Fig. 3a). Deepening the well from 1 to $2 \mathrm{~km}$ allows increasing 
the initial temperature difference by $120 \%$, but due to cooling it will reduce by $23 \%$ in 25 years (Fig. 3b).

The GWS thermal output reaches the maximum at lowest values of the backwater temperature $T_{\text {out }}$ (Fig. 4). Reducing this temperature from 15 to $5{ }^{\circ} \mathrm{C}$ allows increasing the initial thermal output $U_{0}$ from $14 \%\left(H=2 \mathrm{~km}, Q=500 \mathrm{~m}^{3} /\right.$ day $)$ to $26 \%(H=1 \mathrm{~km}$, $Q=1000 \mathrm{~m}^{3} /$ day); however, due to cooling, $U_{0}$ is expected to reduce in 25 years by $17 \%$ and $25 \%$, respectively. Generally, this temperature is not recommended to be maintained below $20{ }^{\circ} \mathrm{C}$ (Alsakhov 2012) due to technical problems of using lower-temperature water in heat supply of buildings. However, in recent years, advanced heat pumps have significantly expanded the temperature range of on-ground heat utilization by lowering water temperature to $4-7{ }^{\circ} \mathrm{C}$ and using it as a low-grade energy source (Fleuchaus and Blum 2017). Therefore, in the calculations below we assumed the temperature of cooled backwater $5{ }^{\circ} \mathrm{C}$ as the minimum for normal heat pump operation. Deeper cooling of backwater may lead to freezing the wells and GWS termination.

Using Eqs. 1-7, we calculated the expected GWS thermal output for the territory of Ukraine at the minimum and maximum well flow rates $Q_{\min }$ and $Q_{\max }$ evaluated as extreme values for the range of aquifer depth $H$ and the minimum and maximum aquifer depths $H_{\min }$ and $H_{\max }$ according to the existing geological settings (Table 1 ). Thus, the created maps (Fig. 5) provide conservative and optimistic estimations to be refined in further case studies.

The maximum GWS thermal output within the range from 0.93 to $1.62 \mathrm{MW}$ at $H_{\min }, Q_{\min }$ to $5.79-9.26 \mathrm{MW}$ at $H_{\max }, Q_{\max }$ is expected in the central and northwest parts of the Crimea and the Black Sea coast associated with the high geothermal flux and thermal water abundance in these aquifers. In contrast, the conditions of GCS operation in Ukrainian crystalline shield are much less favourable thus resulting in much lower GWS thermal output below $0.2 \mathrm{MW}$ at $H_{\min }, Q_{\min }$ and up to $1 \mathrm{MW}$ at $H_{\max }, Q_{\max }$. In the fold province of the Carpathians (Western Ukraine), the thermal output exceeds $0.6 \mathrm{MW}$ at $H_{\min }, Q_{\min }$ and is below $1 \mathrm{MW}$ at $H_{\max }, Q_{\max }$. The estimated GWS thermal output is well correlated to the capacities of such system in the world usually ranging from $1 \mathrm{MW}$ to $10 \mathrm{MW}$ (Alekseenko et al. 2016; IRENA 2018).

The expected profit of GWS operation Pr decreases in time in correlation to gradual cooling of circulating water (Fig. 6) and linearly depends on the flow rate; it decreases by approximately threefold with a decline of the geothermal gradient by half. The largest drop in profit up to $32 \%$ is expected for deeper aquifers $(H=2 \mathrm{~km})$ at the higher flow rate of $1000 \mathrm{~m}^{3} /$ day and with higher initial temperature, whilst the expected profit decline for the lower flow rate of $100 \mathrm{~m}^{3} /$ day is only $10 \%$. Along with this, the profit $\operatorname{Pr}$ increases almost 20 times when deepening the aquifer from $1 \mathrm{~km}$ to $2 \mathrm{~km}$ and when increasing the flow rate 10 times from 100 to $1000 \mathrm{~m}^{3} /$ day.

The specific cost of $1 \mathrm{GJ}$ produced by the GCS in Ukraine depending on location and the operational period varies from 4 to $7 €$, which is at least 2 as little as the average values of this indicator (12-15 $€$ ) in European countries (Mhitaryan and Machulin 2006; IRENA 2018).

The GWS payback period highly depends on the potential profit indicator. At a reservoir depth of $1 \mathrm{~km}$ and a flow rate of $400 \mathrm{~m}^{3} /$ day (Ukrainian crystalline shield in the centre of the country), the payback period is evaluated as 2 years, and for $H=2 \mathrm{~km}$ 


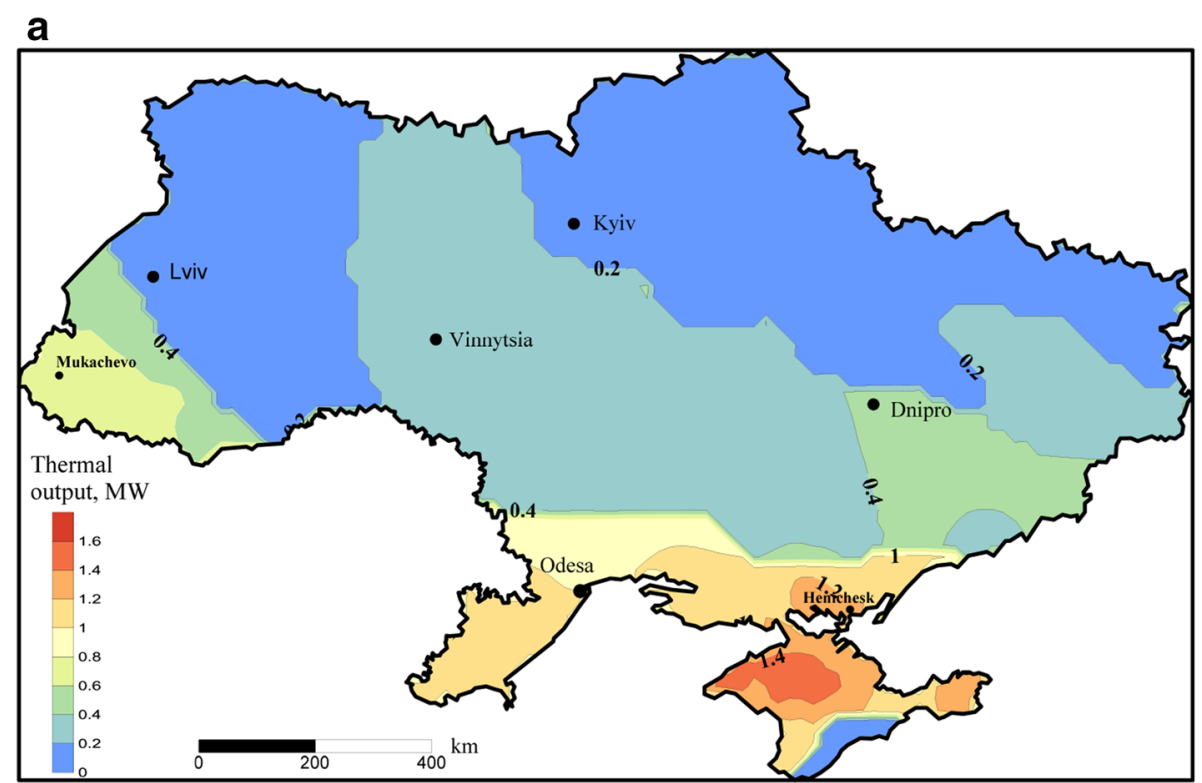

b

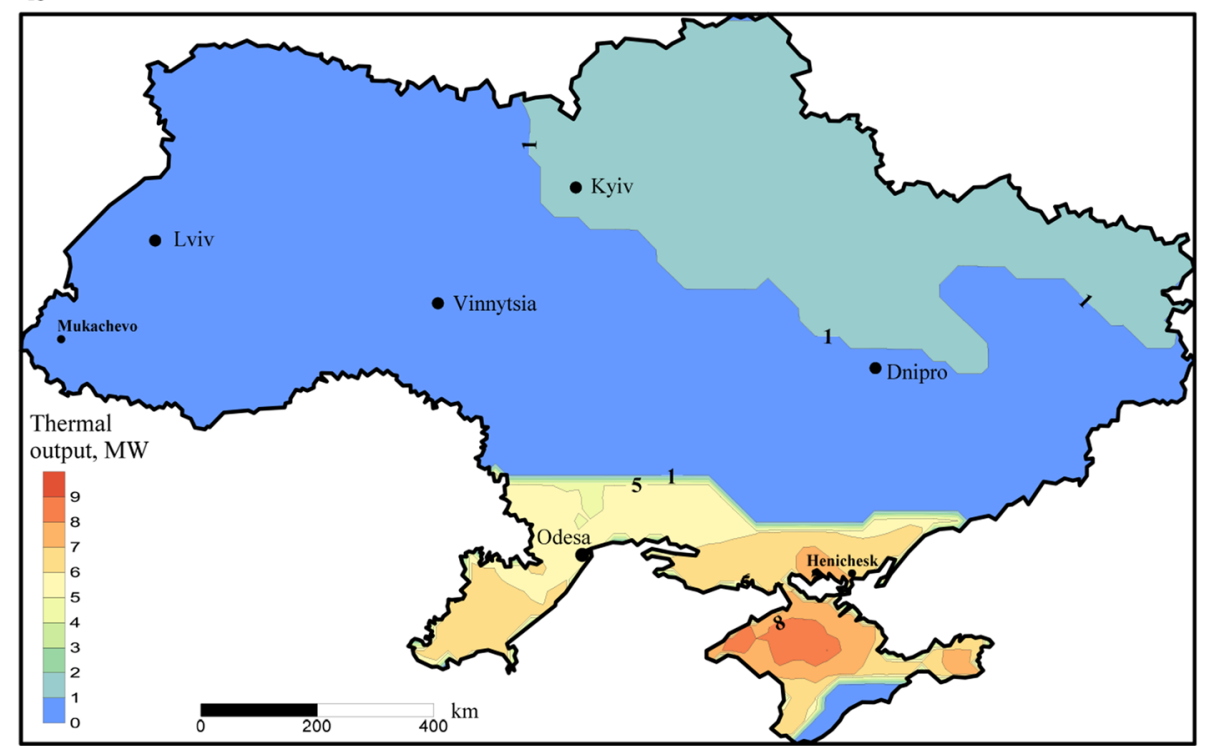

Fig. 5 Distribution of the expected GWS thermal output across Ukraine: $\mathbf{a}$ at the minimum aquifer depth $H_{\text {min }}$ and flow rate $Q_{\min }$, b at the maximum aquifer depth $H_{\max }$ and flow rate $Q_{\max }$

and $Q=100 \mathrm{~m}^{3} /$ day (Dnipro-Donets artesian basin on the north-east of the country) it increases to 7.5 years.

We used Eq. 8 to calculate the NPV taking the discount rate according to the conservative estimate of $5 \%$ per year for Ukraine. The created maps demonstrated more attractive conditions of the GWS operation in southern regions of the country with an elevated geothermal flux (Fig. 7). The expected NPV may be positive (0.5-1 million $€)$ even in eastern areas of the country with a moderate heat flux for geothermal wells installed to a depth of $1 \mathrm{~km}$ with the flow rate of $200 \mathrm{~m}^{3} /$ day. Deepening the aquifer to 

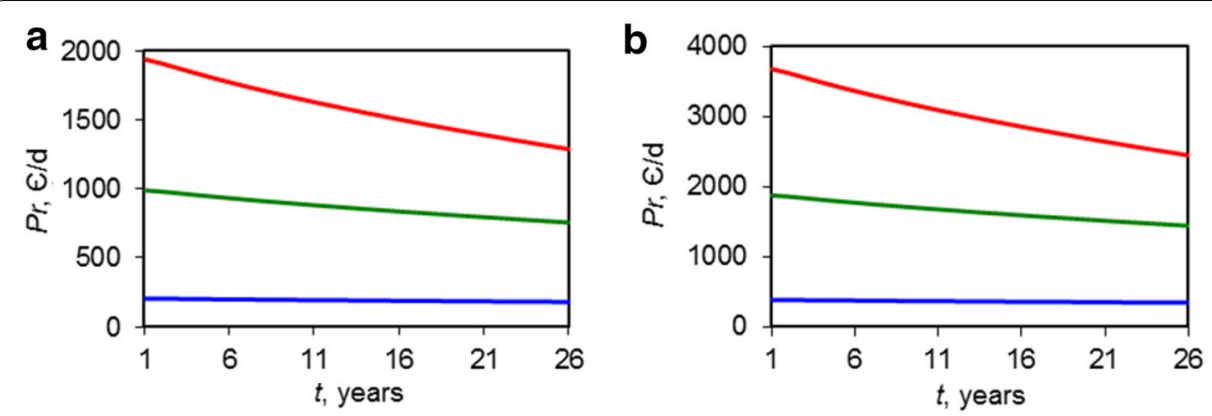

Fig. 6 Profit gained from the GWS by the end of an operational year for different flow rates: $Q=100 \mathrm{~m}^{3} /$ day (blue), $500 \mathrm{~m}^{3} /$ day (green) and $1000 \mathrm{~m}^{3} /$ day (red) at different depths: $\mathbf{a} H=1 \mathrm{~km}, \mathbf{b} H=2 \mathrm{~km}$

$2 \mathrm{~km}$ and increasing the flow rate to $1500 \mathrm{~m}^{3} /$ day in southern regions of the country and Transcarpathia may result in increasing the expected NPV up to 17 million $€$.

Within the provinces of Volyn-Podilsky and Dnipro-Donets artesian basins and the fold province of the Ukrainian crystalline shield mostly on the north of the country (their borders can be seen in Fig. 1), the NPV takes negative values at $H_{\min }, Q_{\min }$, which means that GWS installation is economically unjustifiable for these regions. Deepening the aquifer depth to $H_{\max }$, and increasing the flow rates to $Q_{\max }$ results in expanding negative NPV values to the central regions of the country because the thermal output even from deeper aquifers is insufficient to compensate higher installation costs. In contrast, NPV values remain positive for the depths and flow rates within the evaluated ranges for the southern and north-eastern regions of the country. Thus, deepening the geothermal wells to increase the GWS efficiency might make sense for the north-eastern and southern regions but not for the central and western regions of the country. Of course, all these conclusions should be considered as preliminary and have to be refined by local feasibility studies.

The distribution of the GWS thermal output and the NPV across the country influenced by the depth and flow rate (Figs. 5, 7) significantly differs from the geothermal heat flux distribution (Fig. 1). Thus, the created maps provide a more realistic assessment for potential capacity of GWSs and, with regard to local geological conditions, allow drawing preliminary conclusions in terms of the GWS performance parameters and feasibility in different regions.

Using the same model as above (Eqs. 6, 7), we conducted a preliminary assessment the feasibility and key parameters of two potential geothermal sites in different regions of the country intended for the GWS operation taking into detailed account local geological settings, hydrogeological regime, and existing and expected heat consumers (Table 4). The first site is located near the city of Henichesk (the Black Sea artesian basin), whereas the second one is located in the city of Mukachevo (Transcarpathian Trough); for site locations see Figs. 5 and 7.

Comparing the performance parameters for two sites allows assessing the effect of flow rate and depth. The predicted GWS thermal output in Mukachevo is lower than in Henichesk because of lower groundwater temperature; it is expected to decline by $28.8 \%$ at the end of the operation in comparison with $23.8 \%$ for Henichesk. Due to higher thermal output in Henichesk, the operation of this site might save more fuel equivalent in 


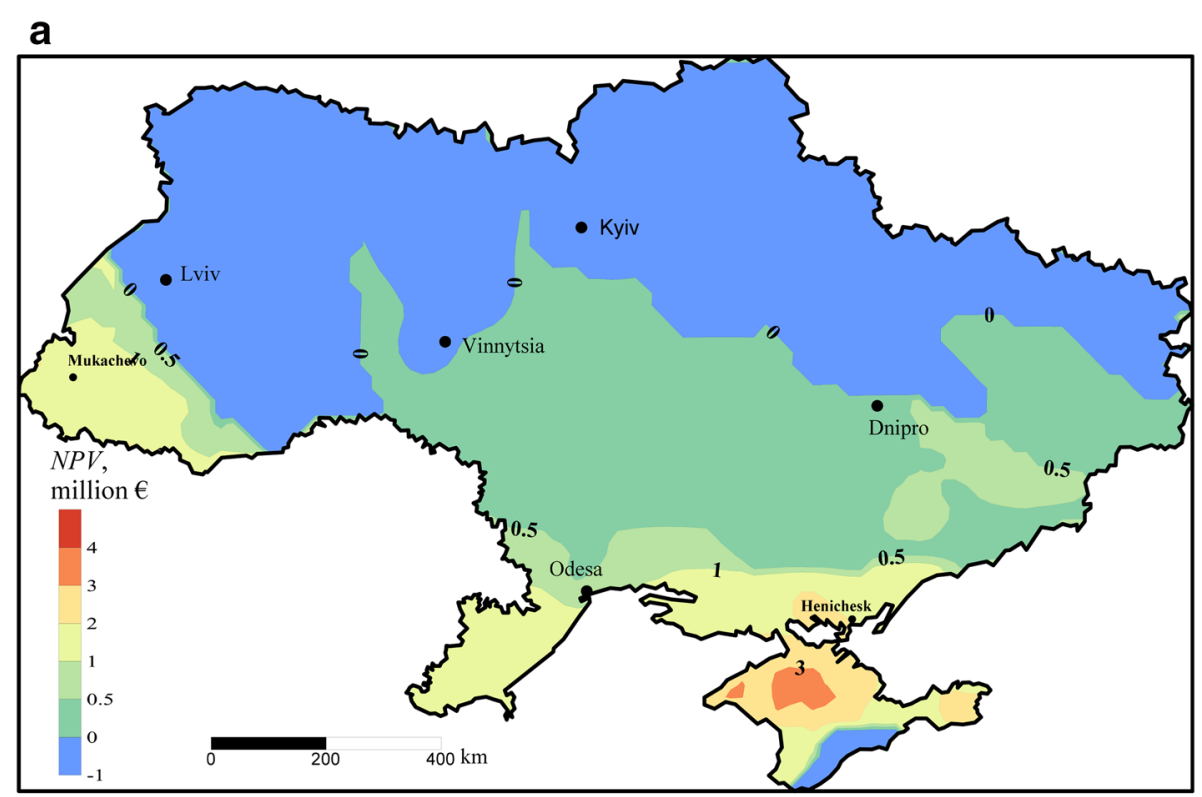

b

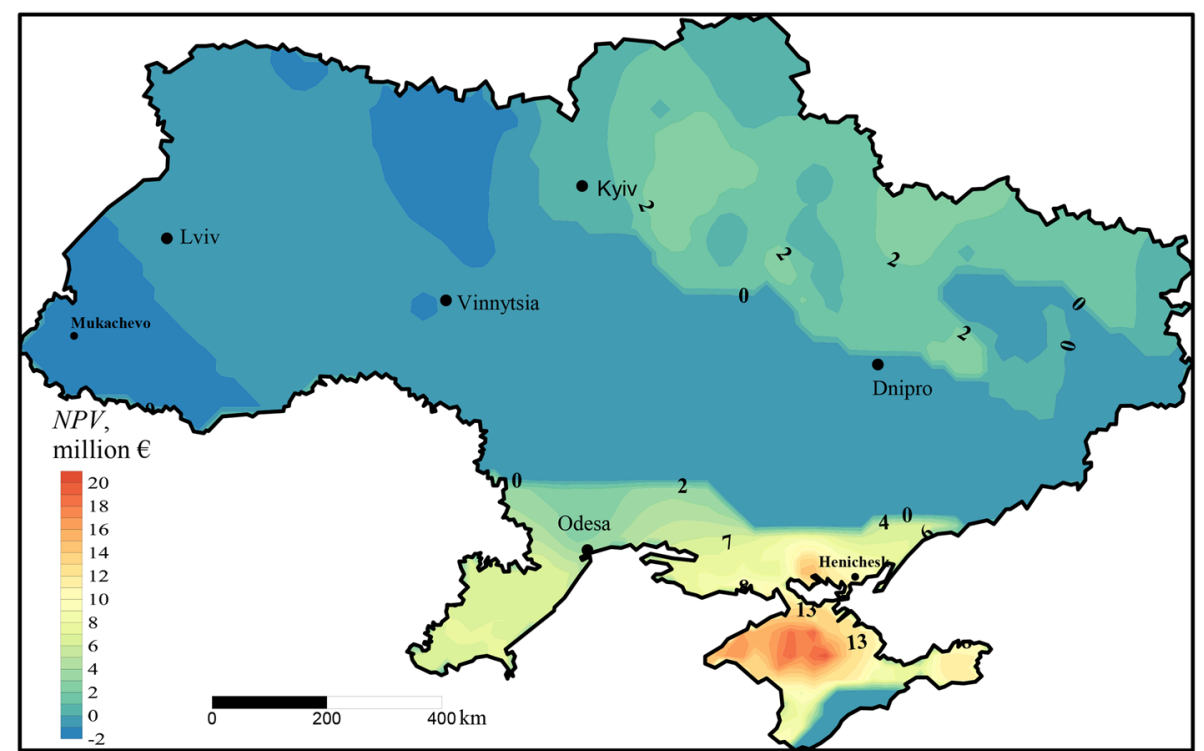

Fig. 7 Distribution of the expected NPV of the GWS operation across Ukraine: a) at minimum aquifer depth $H_{\min }$ and flow rate $Q_{\min }$, b) at maximum aquifer depth $H_{\max }$ and flow rate $Q_{\max }$

comparison with the site near Mukachevo. As both GWS sites are located in the recreation areas, they can be quite attractive for potential investors, but site operation in Henichesk is more dependent on seasonal factors, which may extend the payback period there. At the same time, higher salinity of groundwater near Mukachevo is technically more challenging in comparison with lower salinity near Henichesk.

The NPV of the GWS in Mukachevo is expected to be almost two times less for the GCS in Henichesk because the thermal output at the second site is significantly higher than at the first one. At the same time, lesser depth of the aquifer and relatively higher 
Table 4 Performance indicators of two potential GWSs located in promising areas

\begin{tabular}{lll}
\hline $\begin{array}{l}\text { Parameters and indicators of expected GCS } \\
\text { performance }\end{array}$ & Hydrogeological area & \\
\cline { 2 - 3 } & Fold province of the Carpathian & Black Sea artesian basin \\
\hline Location & Mukachevo & Henichesk \\
Well depth, $\mathrm{m}$ & 700 & 2650 \\
Rock type & Limestone & Sandstones \\
Maximum groundwater temperature at the well & 65 & 76 \\
bottom, ${ }^{\circ} \mathrm{C}$ & & \\
Groundwater salinity, g/dm ${ }^{3}$ & 76.4 & 32.1 \\
Well flow rate, $\mathrm{m}^{3} /$ day & 1050 & 1455 \\
Thermal output, MW (start/end of operation) & $1.32 / 0.94$ & $1.60 / 1.22$ \\
$\mathrm{CO}_{2}$ emission prevention owing to saving conventional fuel, t/a (start/end of operation) \\
Coal & $4632 / 3481$ & $16,020 / 11,380$ \\
Oil & $3812 / 2865$ & $13,190 / 9366$ \\
Natural gas & $2765 / 2078$ & $9564 / 6793$ \\
NPV, million $€$ & 6.1 & 10.5 \\
Potential facilities for heat supply & Industrial and municipal buildings & Sanatoriums, recreation \\
& & centres, and hotels \\
\hline
\end{tabular}

geothermal heat flux near the city of Mukachevo reduce the GWS installation costs and operation thus increasing the NPV and making both sites more comparable in terms of efficient operation.

\section{Conclusions}

The growing need for active use of alternative energy sources in Ukraine is stimulating interest in the exploration of geothermal heat of which theoretical potential greatly exceeds conventional energy sources of the country. Due to high groundwater salinity of thermal waters in Transcarpathian Trough, Volyn-Podilsky plate, Dnipro-Donets depression and the Black Sea coast, open geothermal well systems (GWS) can be considered as a promising way of geothermal heat exploration. This paper focuses on the GWS of simplest doublet design comprising thermal waters pumping to the surface through the production well, on-ground heat recovery, and reinjection of water back to the reservoir through the injection well.

The GWS efficiency is estimated by installation and operation costs as well as the profit to be gained due to geothermal heat recovery. The hydrogeological parameters of the GWS performance were calculated using an existing analytical model of permanent reinjection of cooled water in a two-well design. Calculations showed that the initial temperature difference of abstracted water and reinjected water might decrease by $17-26 \%$ within the ranges of depths and flow rates evaluated for the territory of Ukraine, thus reducing the thermal output and economic efficiency, accordingly. GWS profitability is evaluated by the net present value (NPV) as a generally recognized criterion in investment analysis. The expected profit of the GWS operation linearly depends on the flow rate and decreases by approximately three times with a declining of the geothermal gradient by half.

The created maps of expected GWS thermal output and NPV for the territory of Ukraine provide conservative and optimistic estimations based on hydrogeological 
parameters to be important for pre-feasibility studies of investment projects on geothermal heat exploration. The distribution of the thermal output of the GWS and its NPV across the country influenced by the depth and flow rate significantly differ from the geothermal heat flux distribution. The NPV takes positive values of 0.5-1 million $€$ even in the areas with moderate geothermal flux $\left(60 \mathrm{~mW} / \mathrm{m}^{2}\right)$ and well flow rates ( $200 \mathrm{~m}^{3} /$ day); the NPV is expected to increase up to 17 million $€$ for deeper reservoirs up to $2 \mathrm{~km}$ below the ground. Two potential sites for GWS operation near the cities of Henichesk and Mukachevo (Black Sea artesian basin and the fold province of the Carpathians) located in the areas of high geothermal flux were examined in terms of their potential performance; they have shown comparable NPV values at higher installation costs for the site on the Black Sea artesian basin because of the deeper aquifer.

The further research based on this study may focus on evaluating.

- The pressure and heat losses in geothermal wells using more sophisticated hydraulic and heat transport models that take into detailed account water properties,

- The optimal distances between two and more closely installed GWS systems and flow rate effects on their thermal output,

- Thermal depletion and the issues regarding environmentally sustainable longterm operation.

Besides, the opportunities of the GWS efficiency improvement by successive onground heat recovery should be assessed taking into account the requirements to input and output temperatures in various applications including heat supply, swimming pools, fish farming, greenhouse facilities, heat pumps, and dehydrating agricultural products.

\begin{abstract}
Abbreviations
a: thermal diffusivity of rocks ( $\mathrm{m}^{2} /$ day); $C$ : installation costs for a geothermal well system $(€) ; C_{\mathrm{v}}$ : volumetric heat capacity

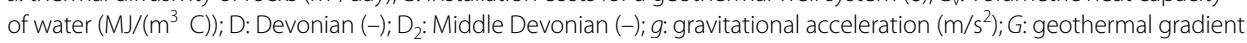
$\left(\mathrm{m} /{ }^{\circ} \mathrm{C}\right) ; \mathrm{GWS}$ : geothermal well system; $H$ : reservoir depth or the depth of the well bottom $(\mathrm{m}) ; H_{0}$ : depth of the neutral layer (m); lo: groundwater head pressure gradient $(-)_{;} J_{2}$ : Middle Jurassic (-); $k$ : rock conductivity (m/day); K: Cretaceous (-); $k_{z}$ : safety factor for pumps (-); l: distance between injection and pumping wells (m); $L_{w}$ : length of the well (m); rm: aquifer thickness (m); $n$ : active porosity (-); $N_{1}^{2}$ : Middle Miocene $(-)$; $\mathrm{N}_{1}^{3}$ : Upper Miocene $(-)$; $N_{\text {abst: }}$ pump rate for water abstraction $\left(\mathrm{m}^{3} /\right.$ day); $N_{\text {inj: }}$ pump rate for water injection ( $\mathrm{m}^{3} /$ day); NPV: net present value $(€) ; P$ : Permian $(-)$; $P_{\text {aq: }}$ : pressure in the aquifer $(\mathrm{Pa}) ; P_{\text {inj: }}$ pressure of injected water $(\mathrm{Pa}) ; P_{\mathrm{w}}$ : per cent share of the equipment costs with respect to the total drilling costs (\%); Pr: profit (€); PR: Proterozoic (-); q: geothermal heat flux $\left(\mathrm{W} / \mathrm{m}^{2}\right)$; $Q$ : well flow rate $\left(\mathrm{m}^{3} /\right.$ day); $r_{\mathrm{t}}$ : radius of well thermal influence $(m) ; r_{w}$ : well radius $(m) ; s_{\text {el: }}$ electricity tariff for consumers in industries $(€ / \mathrm{kWh}) ; s_{\text {th: }}$ tariff for thermal energy $(€ / \mathrm{kWh}) ; s_{w}$ : drilling cost per a running metre of a well $(€ / \mathrm{m}) ; S_{h}$ : cost of generated heat $(€)$; $S_{p}$ : cost of power consumed by the pumps $(€) ; t$ : time (days); $t_{\mathrm{op}}$ : operation time (days); $T_{3}$ : Upper Triassic $(-)_{;} T_{\mathrm{in}}$ : water temperature before use $\left({ }^{\circ} \mathrm{C}\right)$; $T_{\text {inj: }}$ temperature of injected water $\left({ }^{\circ} \mathrm{C}\right) ; T_{\text {out }}$ : water temperature after cooling on the ground $\left({ }^{\circ} \mathrm{C}\right) ; T_{0}$ : water temperatures in rocks at a depth of the neutral layer $\left({ }^{\circ} \mathrm{C}\right)_{;} T_{\mathrm{b}}$ : water temperatures at the injection well bottom $\left({ }^{\circ} \mathrm{C}\right) ; T_{\mathrm{aq}}$ : groundwater temperature in the aquifer $\left({ }^{\circ} \mathrm{C}\right)$; $U$ : thermal capacity (heat output) of a GWS $(W) ; V_{p}$ : volume of rocks through which water circulates $\left(\mathrm{m}^{3}\right) ; W$ : power consumption $(\mathrm{W}) ; \eta_{\mathrm{p}}$ : pump efficiency $(-)$; $\eta_{\mathrm{tr}}$ : efficiency of mechanical transmission of rotational motion from the engine to the pump $(-) ; \lambda$ : thermal conductivity of rocks $\left(\mathrm{W} /\left(\mathrm{m}{ }^{\circ} \mathrm{C}\right)\right) ; \rho_{\text {inj: }}$ density of injected water $\left(\mathrm{kg} / \mathrm{m}^{3}\right)$.
\end{abstract}

\title{
Acknowledgements
}

Prof. I. Sadovenko (Department of Hydrogeology and Engineering Geology of National Mining University) is highly acknowledged for his support and helpful discussions.

\section{Authors' contributions}

DR formulated the idea of research and developed the program for calculations. Ol performed hydrogeological assessment and calculations. Analysis of results, mapping and conclusions were made together by both authors. Both authors read and approved the final manuscript. 
Availability of data and materials

The datasets used and/or analysed during the current study are available from the corresponding author on reasonable request.

\section{Competing interests}

The authors declare that they have no competing interests.

Received: 17 January 2019 Accepted: 20 June 2019

Published online: 03 July 2019

\section{References}

ADEME. French know-how in the field of geothermal energy: district heating and electricity generation systems. Angers: ADEME. 2013. p. 20. ISBN 978-2-35838-353-0. http://www.geothermie-perspectives.fr/sites/default/files/frenc h_know-how-geothermal-energy.pdf. Accessed 2 Dec 2018.

Alekseenko SV, Borodulin VY, Gnatus NA, Nizovtsev MI, Smirnova NN. Problems and outlooks for pethrothermal power engineering (review). Thermophys Aeromech. 2016;23:1-16. https://doi.org/10.1134/S0869864316010017.

Alsakhov AB. Renewable energy. Moscow: Fizmatlit; 2012.

Arens VZ. Physico-chemical geotechnology. Moscow: Publishing House of the Moscow State Mining University; 2001.

Bai M, Patil PA. The identification of growth barriers for exploitation of geothermal energy in China. Energy Sourc Part A. 2014:36(22):2482-91. https://doi.org/10.1080/15567036.2012.738285.

Bayer P, Rybach L, Martinez Corona Jl, Gibon T. Geothermal power. In: Green Energy Choices, editor. The benefits, risks and trade-offs of low-carbon technologies for electricity production. New York: UN; 2016. p. 356-95. https://doi. org/10.18356/db56bd02-en.

Berdan G. A restoration plan for the Hanna, Wyoming. Underground coal gasification site in carbon county. Laramie: Western Research Institute; 1986

Bertani R. Geothermal power generation in the world, 2010-2014 Update Report. In: Proceedings world geothermal congress, Melbourne, Australia. 2015. https://www.geothermal-energy.org/pdf/IGAstandard/WGC/2015/01001.pdf. Accessed 9 Oct 2018.

Bugai VS. Effect assessment of design parameters of heat supply geothermal circulation system on electric power of a force pump. Energy Sav Power Eng Energy Audit. 2014;10:7-11.

Busby J, Terrington R. Assessment of the resource base for engineered geothermal systems in Great Britain. Geotherm Energy. 2017;5:7. https://doi.org/10.1186/s40517-017-0066-z.

Cabrera A, Blarasin M, Luciana M. Groundwater age and hydrothermalism of confined aquifers in the Argentine Pampean plain. Geotherm Energy. 2017;5:6. https://doi.org/10.1186/s40517-017-0064-1.

Camp DW, White JA. Underground coal gasification: An overview of groundwater contamination hazards and mitigation strategies. Washington: US Dept of Energy: LLNL; 2015.

Dolinskyi AA, Obodovych OM. World experience use of geothermal energy and prospects of its development in Ukraine. Visnyk NAN Ukrainy. 2016;3:62-9. https://doi.org/10.15407/visn2016.03.062.

Dolinskyi AA, Rezakova TA. Contribution of geothermal energy to energy independence of Ukraine. Thermophys Indus Heat Eng. 2017;2:6-11. https://doi.org/10.31472/ihe.2.2017.01

Dychkovskyi RO. Forming the bilayer artificially shell of georeactor in underground coal gasification. Naukovyi Visnyk Natsionalnoho Hirnychoho Universytetu. 2015;5:37-42.

Erdlac Jr RJ, Trentham RC, Armour L, Lee R, Miller B. Adding to the geothermal energy portfolio from deep sedimentary basins. In: Pritchett J. Technical program chairman, geothermal resources-securing our energy future: geothermal resources council transactions; 2006. p. 875-83.

Filatov S, Zaharchenko N. The cost of deep drilling wells: methodological tool development. Neftegazovaya Vertikal. 2012:5:54-8.

Fleuchaus P, Blum P. Damage event analysis of vertical ground source heat pump systems in Germany. Geotherm Energy. 2017;5:10. https://doi.org/10.1186/s40517-017-0067-y.

Gehringer M, Loksha V. Geothermal Handbook: Planning and Financing Power Generation. ESMAP Technical Report 002/12. 2012.

Gordienko VV, Gordienko IV, Zavgorodnyaya OV, Usenko OV. Thermal field of the territory of Ukraine. Kyiv: Znanie; 2002.

Hashida T, Hayashi K, Niitsuma H, Matsuki K, Tsuchiya N, Nakatsuka K. Investigation of heat extraction from supercritical geothermal reservoirs. In: Proceedings world geothermal congress, Kyushu, Tohoku, Japan. 2000. https://www. geothermal-energy.org/pdf/IGAstandard/WGC/2000/R0616.PDF. Accessed 8 Nov $2018 .$.

IRENA. REmap 2030 renewable energy prospects for Ukraine. Abu Dhabi: IRENA; 2015.

IRENA. Renewable power generation costs in 2017. Abu Dhabi: IRENA; 2018.

Ishlinskyi AY. Polytechnic dictionary. Moscow: Sovetskaya Enciklopediya; 1989.

Kepinska B. Geothermal energy country update report from Poland, 2010-2014. In: Proceedings world geothermal congress, Melbourne, Australia. 2015. https://pangea.stanford.edu/ERE/db/WGC/papers/WGC/2015/01039.pdf. Accessed 18 Oct 2018

Kong Y, Pang Z, Shao H, Hu S, Kolditz O. Recent studies on hydrothermal systems in China: a review. Geotherm Energy. 2014;2:19. https://doi.org/10.1186/s40517-014-0019-8.

Limarenko AN. Potential and necessity to develop nontraditional renewable energy in Ukraine. East Eur J Enterprise Technol. 2012;8(65):14-9.

Lukinov V, Prykhodchenko V, Prykhodchenko O, Tykhonenko V. Changes in density of carbon atomic packing in natural formations. Solid State Phenom. 2018;277:202-12. https://doi.org/10.4028/www.scientific.net/SSP.277.202.

Mahler A, Magtengaard J. Country update report for Denmark. Proceedings World Geothermal Congress, Bali, Indonesia. 2010. https://www.geotermi.dk/media/3784/wgc2010countryupdate.pdf. Accessed 12 Nov 2018. 
Maliarenko VA, Haletych IK, Verheles YI. Renewable energy sources for Kharkiv region: current state, trends and prospects. Energy Saving Power Eng Energy Audit. 2012;7:36-43.

Mhitaryan NM, Machulin VF. Ukrainian energetics development problems: renewable and non-traditional energy. Sci Innov. 2006;2:63-75. https://doi.org/10.15407/scin2.02.063.

Michaelides ESM. Alternative energy sources. Berlin: Springer; 2012.

Moya D, Paredes J, Kaparajua P. Method for the technical, financial, economic and environmental pre-feasibility study of geothermal power plants by RETScreen—Ecuador's case study. MethodsX. 2018:5:524-31. https://doi.org/10.1016/j. mex.2018.05.010.

National Atlas of Ukraine. Kyiv, SSPE "Kartographia"; 2007.

Oradovskaya AY, Lapshin NN. Sanitary protection of groundwater intakes. Moscow: Nedra; 1987.

Pivnyak G, Dychkovskyi R, Bobyliov O, Cabana CE, Smoliński A. Mathematical and geomechanical model in physical and chemical processes of underground coal gasification. Solid State Phenom. 2018;277:1-16. https://doi.org/10.4028/ www.scientific.net/SSP.277.1.

Red'ko AA, Bugai VS. Optimization of geothermal circulating heat supply system parameters. Naukovyi Visnyk Natsionalnoho Hirnychoho Universytetu. 2010;5:99-105.

Reinsch T, Huenges E, Bruhn D, Thorbjörnsson I, Gavriliuc R, van Wees J. Geothermal R\&D, new projects and perspectives for basic scientific research. In: Proceedings European Geothermal Congress, Strasbourg, France. 2016.

Rudakov D, Sadovenko I, Inkin A. Modeling of heat transport in an aquifer during accumulation and extraction of thermal energy. Naukovyi Visnyk Natsionalnoho Hirnychoho Universytetu. 2012;1:40-5.

Rybach L. The future of geothermal energy and its challenges. In: Proceedings world geothermal congress, Bali, Indonesia. 2010. https://pdfs.semanticscholar.org/99d8/9da4e2df23c581f7b7da6b375408ebc63713.pdf. Accessed 12 Sep 2018.

Shestopalov VM, Sitnikov AB, Lyalko VI, Pashkovsky IS. Water exchange in hydrogeological structures of Ukraine. Methods of studying water exchange. Kiev: Naukova dumka; 1988.

Shnell J, Hiriart G, Nichols K, Orcutt J. Energy from ocean floor geothermal resources. In: Proceedings world geothermal congress, Melbourne, Australia. 2015. https://pangea.stanford.edu/ERE/db/WGC/papers/WGC/2015/37011.pdf. Accessed 11 Nov 2018.

Shulyupin A, Chernev I. Some methods for reducing of steam deficit at geothermal power plants exploitation: experience of Kamchatka (Russia). Geotherm Energy. 2015;3:23. https://doi.org/10.1186/s40517-015-0042-4.

Tester JW, Anderson BJ, Batchelor AS, Blackwell DD, Pippo R, Drake EM, Garnish J, Livesay B, Moore MC, Nichols K, Petty S, Toksöz MN, Veatch RW. The future of geothermal energy in the 21 century. Impact of enhanced geothermal systems (EGS) on the United States. Cambridge: MIT Press; 2006.

Timoshuk V, Tishkov V, Inkin O, Sherstiuk E. Influence of coal layers gasification on bearing rocks. Geomechanical processes during underground mining. In: Proceedings of the School of Underground Mining, Dnipropetrovs'k-Yalta, Ukraine; 2012, p. 109-113.

Zeng Y, Zhou W, LaMoreaux J. Single-well circulation systems for geothermal energy transfer. J Environ Earth Sci. 2017;76:296. https://doi.org/10.1007/s12665-017-6621-X.

\section{Publisher's Note}

Springer Nature remains neutral with regard to jurisdictional claims in published maps and institutional affiliations.

\section{Submit your manuscript to a SpringerOpen ${ }^{\circ}$ journal and benefit from:}

- Convenient online submission

- Rigorous peer review

- Open access: articles freely available online

- High visibility within the field

- Retaining the copyright to your article

Submit your next manuscript at $\boldsymbol{\nabla}$ springeropen.com 